\title{
Review of air disturbance technology for plant frost protection
}

\author{
Yongguang $\mathrm{Hu}^{1}$, Eric Amoah Asante ${ }^{1,2}$, Yongzong Lu ${ }^{1}$, Ashraf Mahmood ${ }^{1}$, \\ Noman Ali Buttar ${ }^{1}$, Shouqi Yuan ${ }^{1,3^{*}}$ \\ (1. School of Agricultural Equipment Engineering, Jiangsu University, Zhenjiang 212013, China; \\ 2. Faculty of Engineering, Koforidua Technical University, Koforidua, Ghana; \\ 3. Research Center of Fluid Machinery Engineering and Technology, Jiangsu University, Zhenjiang 212013, China)
}

\begin{abstract}
Confronted with severe frost damage to plants, methods, technologies and equipment have been developed and applied during the past century. The paper presents a comprehensive review on the most effective and active technology to protect plants from radiation frost based on air disturbance technology. The working principle of the technology was elaborated with frost protection mechanism, structures and applicability of three types of working patterns: conventional wind machines, selective inverted sink and portable vertical blowing. As an automatic mechanized technology, control strategy, applicable occasion and proper parameters are introduced for each type of working pattern. The operation of the technology and equipment depends on plant critical temperature, prevailing climatic conditions, thermal inversions strength, as well as costs. The frost protection performance and effectiveness of conventional horizontal wind machines, selective inverted sinks and helicopters are discussed and compared from the cost-effectiveness and application aspects, and the feasibility of selective inverted sinks is still controversial. Therefore, conventional wind machines are the best choice for plant frost protection and consequently are widely used in temperate and subtropical areas throughout the world. The frost protection application with helicopters is not easy to use during the frost nights with high cost. The paper also provides researchers with some perspectives on improving air disturbance technology and its equipment, and some practice recommendations for growers.

Keywords: thermal inversion, plant frost protection, air disturbance technology, wind machine, cost-effectiveness, control technology

DOI: $10.25165 /$ j.ijabe.20181103.3172
\end{abstract}

Citation: Hu Y G, Asante E A, Lu Y Z, Mahmood A, Buttar A N, Yuan S Q. Review of air disturbance technology for plant frost protection. Int J Agric \& Biol Eng, 2018; 11(3): 21-28.

\section{Introduction}

Growers of fruits, vegetables, and several cash crops in severe freeze-prone areas encounter huge economic loss annually as a result of frost damage ${ }^{[1-3]}$. In April, 2007 the central and southeast portion of the U.S were hit with the worse freezing injury to many commercial crops, leading to estimated losses of over 2 billion dollars ${ }^{[4-7]}$. Therefore frost is considered a climatic hazard which is responsible for yield loss and can cause an injury to orchard trees $^{[8]}$. Under certain critical temperatures the injury caused by frost is mostly a major limiting factor for the control of plant distribution on earth ${ }^{[9,10]}$. These temperatures differ from plant to plant and the development stage. It is the minimum temperature at which the plant can resist any serious injury for at least 30 $\min ^{[9,11,12]}$. In general frost at $-2^{\circ} \mathrm{C}$ to $-3^{\circ} \mathrm{C}$ is expected to cause damage to some horticultural crops if it stays over a period of at least one hour; $-1{ }^{\circ} \mathrm{C}$ for an extended period such as 3-4 $\mathrm{h}$ can also cause similar damage ${ }^{[13]}$. The injuries caused by frost are specifically common in temperate regions of the world during

\section{Received date: 2017-07-05 Accepted date: 2018-05-04}

Biographies: Yongguang $\mathbf{H u}, \mathrm{PhD}$, Professor, Research interest: agro-biological environmental engineering, monitoring and control of frost protection, Email: Email: deerhu@163.com; Eric Amoah Asante, PhD candidate, Research interest: agricultural mechanization, Email: eaamoah@, yahoo.com; Yongzong Lu, PhD candidate, Research interest: agro-biological environmental engineering, monitoring and control of frost protection, Email: luyongzong@126.com; Ashraf Mahmood, PhD candidate, Research interest: agrometeorology, Email: jikkik90@yahoo.com; Noman Ali Buttar, PhD candidate, research interest: biometeorology, Email: noman_buttar@yahoo.com. *Corresponding author: Shouqi Yuan, PhD, Professor, Research interest: fluid mechanics, Address: 301 Xuefu Road, Zhenjiang 212013, China. Tel: +86-511-88780007, Email: shouqiy@ujs.edu.cn. spring $^{[14-16]}$. As a result, plants in temperate regions have developed mechanisms to endure the low temperature stress during winter ${ }^{[17-19]}$. But the ability of the plant to resist frost can be measured by the lethal temperature of plant tissue ${ }^{[20,21]}$. The temperature is generally regarded as the one at which about $50 \%$ to $90 \%$ of plants' reproductive organs could be killed ${ }^{[22-24]}$.

Due to dissimilar weather conditions, there are two main types of frost: advection and radiation frost ${ }^{[25,26]}$. The radiation frosts (hoar frosts and black frosts) are caused by long-wave radiation loss of heat from the ground and solid objects such as grape shoots under clear skies and calm wind conditions ${ }^{[27,28]}$. This develops a thermal inversion layer and air temperature near ground drops below $0^{\circ} \mathrm{C}$. The advection frost occurs as a result of a large cold air mass at subfreezing temperatures and wind exceeding $4.5 \mathrm{~m} / \mathrm{s}$ moving into a given area ${ }^{[29,30]}$. Many studies have confirmed that protection of plants from frost damage can be made more effective by reducing ice nucleation temperature and impede the proliferation of ice from the outside to the interior of a plant ${ }^{[5,31-34]}$. To prevent or reduce frost damage, an expansive range of passive and active methods were developed ${ }^{[35,36]}$. The passive methods include plant and site selection, appropriate use of cultivation and management practices, and modification of the physical environment around plants. However, under severe frost conditions, passive methods are often inadequate to protect plants ${ }^{[37,38]}$. This is because it is not easy to predict protection by plant-induced frost tolerance through environmental conditions ${ }^{[39]}$. For effective and reliable frost protection, a number of active methods such as wind machines, sprinkler irrigation, and open air heaters are used ${ }^{[40]}$. These methods are implemented just before or during a frost night to prevent ice formation within sensitive plant tissues. 
Active frost protection methods, such as air disturbance technology (wind machines, selective inverted sink (SIS), and frost protection helicopters) has gained high reputation because it provides energy conservation and can be used for several seasons when compared with other active or passive methods. Therefore, this article seeks to present a comprehensive review on the topic of air disturbance technology and equipment for frost protection. The publications are critically reviewed and classified into three major categories. The first is on the effectiveness of using conventional wind machines for plant frost protection. The second category is on the effectiveness of SIS. The third category focuses on the effectiveness of frost protection helicopters.

This article describes the working principle of air disturbance technology and covers the control strategies of the technology. Its effectiveness for plant frost protection with reference to findings of previous researches has been presented. The advantages and limitations of each air disturbance technology and equipment are compared. Best management practices are discussed with its selection under different conditions. Finally, some perspectives on improving air disturbance technology and some practice recommendations are provided for researchers and growers.

\section{Working principle of air disturbance technology}

\subsection{Horizontal forced ventilation}

Air temperature during a thermal inversion actually increases with altitude to the top of an air layer which is opposite to the normal condition where air temperature decreases with height ${ }^{[41,42]}$. The warm air in an inversion is critical to the operation of wind machines for frost protection ${ }^{[37]}$. Conventional wind machines and circular-plate fans are stationed at fixed points with the fans slightly tilted downwards but to achieve efficient and large-scale frost protection, mobile wind machines have also been produced ${ }^{[43]}$. Figure 1 shows the working principle of a wind machine and its schematic cross-section located in a tea field. A large machine is capable of protecting the area of about $4 \mathrm{hm}^{2}$. Greater cumulative effect could be achieved with more machines set up in fields. They operate by sweeping heavy cold and moist air near the ground and allow it to be replaced by the warmer inversion layer air so as to avoid stratification ${ }^{[44,45]}$. Wind machines provide protection by increasing the downward sensible heat flux density during a radiation frost ${ }^{[37]}$. As the air pushed by the wind machine moves past foliage, friction between the air and the plant generates heat and this warm air replaces the colder ambient air in contact with the plant. The amount of protection afforded depends on thermal inversion strength. In general, the incremental temperature after starting the fans is close to the mean of the inversion strength.

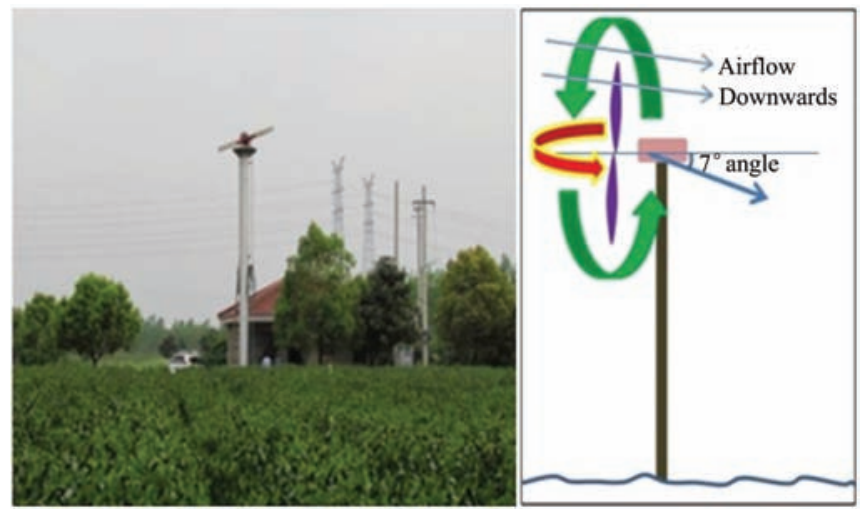

Figure 1 Wind machine and schematic cross-section

\subsection{Ground vertical blowing}

The selective inverted sink (SIS) (shown in Figure 2 and 3) is actually a fan of low specific number with a vertical shaft and a horizontal propeller, and is housed in a chimney-like structure to break thermal inversion layer for frost protection ${ }^{[46]}$. Conversely to the conventional wind machine, the vent near the base of the SIS allows cold air near ground to be pulled up through the duct. This creates a suction effect that draws warmer air down to the ground ${ }^{[47]}$. The inverted drain and extraction of air depends on the distance between the lower rim and the ground. The interior of the duct may be provided with a variety of vanes or blades to impart a certain direction to the atmospheric fluid in accordance with the laws governing the mechanics of fluids. Consequently, air mass coming out from the top of the duct may also contributes to improving air mixing across the inversion layer ${ }^{[48]}$.

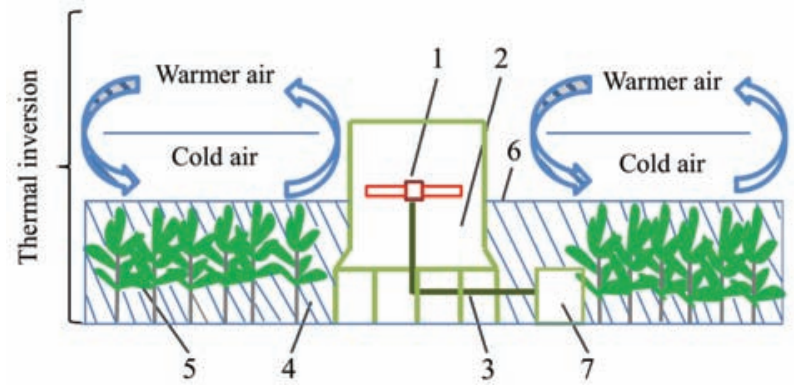

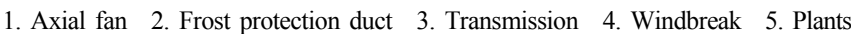
6. Bracket 7. Motor.

Figure 2 Schematic cross-section of a selective inverted sink for frost protection

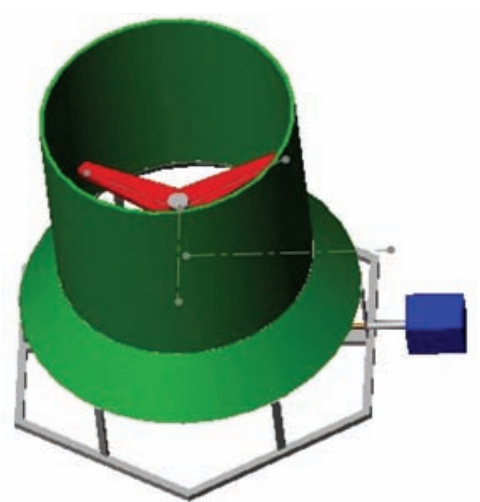

Figure 3 Three-dimensional structure of a selective inverted sink

\subsection{Aerial vertical blowing}

Frost protection helicopters are sometimes used to push warmer air down to plant canopies to replace the cold air layer near ground only when a black frost is forecast ${ }^{[49]}$. During frost nights, helicopters hover over the inversion layer, and their running rotors push warmer air aloft downwards to the plant canopy. This helps to increase near ground air temperature, and frost damage could be avoided or reduced ${ }^{[50]}$. Figure $4 \mathrm{a}$ shows an unmanned helicopter flying above the inversion layer in a tea field and Figure $4 \mathrm{~b}$ shows its working principles with a schematic cross-section. The technology works best for radiation frost events during cloudless, low wind to no wind nights. However, the method is not reliable if minimum temperature falls below $-5^{\circ} \mathrm{C}$ or at wind speed above $2.5 \mathrm{~m} / \mathrm{s}$, and also not effective for advection frost ${ }^{[51]}$.

In order to cover a larger protected area portable wind machines have been developed. Besides, such portable wind machine could be adjusted to different height. The machine is capable of being extended to a significant height for operation in preventing frost and can be shortened in height for easy portability 
from place to place. The support tower is adapted for mounting to a readily transportable platform, such as a wheeled vehicle which may be a trailer. The propellers are mounted on a vertical axis, which provides a much better circulation of warm upper level air through the plant area than does a horizontal axis configuration. To demonstrate this reliability, Tow and Blow Limited developed a portable wind machine to provide reliable frost protection for all

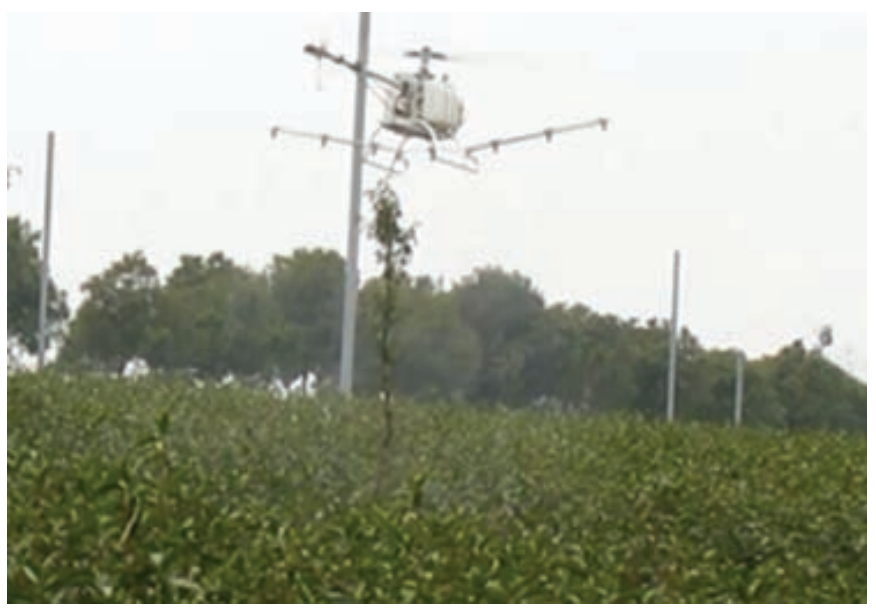

a. Unmanned helicopter plants under a variety of freezing conditions ${ }^{[53]}$. The shrouded impeller guarantees efficiency in protecting frost-prone plants, regardless of the landscape. The portable wind machine ensures that freezing plants are protected across a greater area at different heights because it oscillates and is fixed on an adjustable boom. Therefore, the portable wind machine has the advantage to serve both small and large horticultural farms.

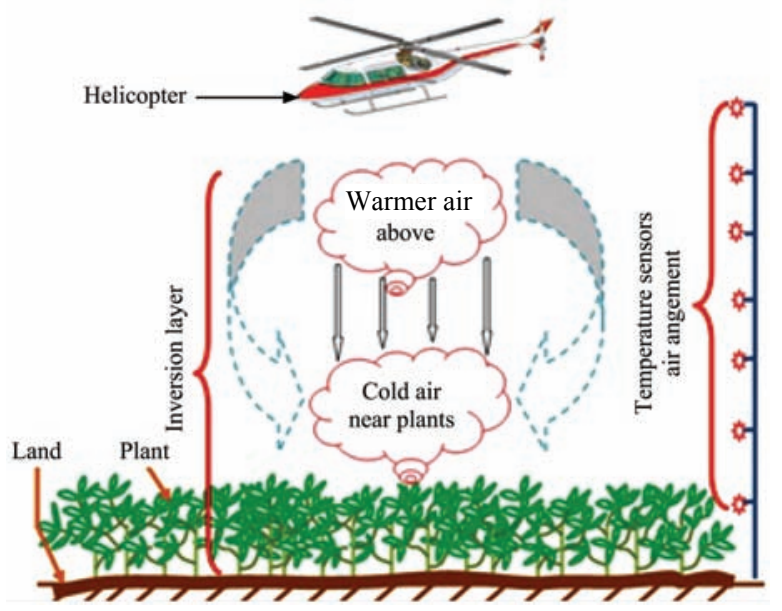

b. Working principle

Figure 4 Unmanned helicopter used for frost protection

Table 1 Representative work on plant frost protection using air disturbance technology

\begin{tabular}{|c|c|c|c|}
\hline Author/Organization & Year & System type & Objective of the work \\
\hline Crawford & 1964 & CWM & Heating requirements of wind machine for effective frost protection \\
\hline Bates & 1972 & CWM & Reliability assessment of temperature inversions and modifications produced by a wind machine. \\
\hline Davis & 1977 & CWM & $\begin{array}{l}\text { Evaluation of the effectiveness of a wind machine under different temperature inversions and to indicate the } \\
\text { effective areas of application. }\end{array}$ \\
\hline Bates and Lombard & 1978 & CWM & Determine the existence of inversions and beneficial effects of wind machines to offer frost protection to orchards. \\
\hline Ribeiro et al. & 2006 & CWM & Effects of starting fans before reaching plant's critical temperature. \\
\hline Tow and Blow Limited & 2012 & CWM & Portable frost protection under a variety of freezing environments. \\
\hline Yazdanpanah and Stigter & 2011 & SIS & Investigate the influence of SIS systems using both phonological and meteorological data. \\
\hline Battany & 2012 & SIS & Compering performance of SIS with CWM on temperature changes under similar radiation frost conditions. \\
\hline Hu et al. & $2015 \mathrm{a}$ & SIS & $\begin{array}{l}\text { Frost protection effectiveness of vertical blowing fans (VBFs) in a steeped slope vineyard and in rippling } \\
\text { topography tea plantation. }\end{array}$ \\
\hline Miller et al. & 1971 & $\mathrm{H}$ & Effectiveness of helicopter for frost protection. \\
\hline Miles and Hinz & 1976 & $\mathrm{H}$ & Evaluating the ability of helicopters to increase plant canopy air temperature. \\
\hline $\mathrm{Hu}$ et al. & $2015 b$ & $\mathrm{H}$ & Determining the best flight parameter combination for optimal frost protection effect. \\
\hline
\end{tabular}

Note: * Conventional wind machine (CWM); Selective Inverted Sink (SIS), and Helicopters (H).

\section{Control for air disturbance technology}

Operating wind machines to diffuse air for protecting plants from frosts involve positioning and controlling. These systems are traditionally operated manually. However, certain meteorological factors make the control problematic and therefore automation of the system operation is required ${ }^{[51,52]}$. This is because when natural meteorological conditions, such as wind speed, thermal inversion and humidity around plants, approach damaging level, the system start-up could trigger fan operation, and then stop it when the situation is normalized ${ }^{[37]}$. One way to automate the system's operation is to place an array of temperature sensors $0.6-1.2 \mathrm{~m}$ above ground along the slope in the vineyard, including the coldest part of the field ${ }^{[51,53]}$. The effectiveness of frost protection does not only depend on the performance of the wind machine itself, but on the arrangement in the field and the depression angle of the fan. The depression angle ranges between $6^{\circ}$ and $9^{\circ}$ for conventional wind machines ${ }^{[47]}$, and $15-50^{\circ}$ for circular-plate fans; but the higher the depression angle is, the smaller the influenced area is, and vice versa. Therefore, areas just under the machine tower are less protected, or in some cases have no protection. The solution to this problem is to have machines arranged in series so that the preceding fans could disturb cold air under the next one ${ }^{[54]}$. Fan swing scope of $60-120^{\circ}$ with a maximum swing period of $2-5 \mathrm{~min}$ is also desirable to ensure that the air would not re-stratify. The swing scope can sometimes be $360^{\circ}$. However, the best frost fighting can be achieved when the machine is positioned on the boundary to push air in the natural 
cold air drift, and allowed to oscillate through $108^{\circ}$. Therefore a complete revolution of $360^{\circ}$ is not recommended because the effective pattern of a wind machine is not circular due to cold air drift $^{[55]}$. The positioning of the machine, motor power and tower height depend on the topography, the plants to be protected and the density of the canopy. All these control strategies can be effective if temperature sensors are located at the topmost inversion height and the plant canopy including the coldest part of the field. This is to ensure that the system only starts up when there is an inversion with near ground temperature approaching critical temperature of the plant. In many cases, fans start when canopy temperature approached $0^{\circ} \mathrm{C}$ and stop when the thermal inversion was over, or plant canopy temperature rose above $0^{\circ} \mathrm{C}^{[37]}$.

In the case of helicopters, the optimum flying height for effective utilization is generally between 20 and $30 \mathrm{~m}$ and the flight speed is $8-40 \mathrm{~km} / \mathrm{h}$. However, the influence of the flight height on plant canopy air disturbance is greater than that of the flight speed $^{[50]}$. The recommended pass frequency varies between 30 and $60 \mathrm{~min}$, therefore waiting too long between passes will permit the plants to supercool and that can lead to severe damage ${ }^{[51,56]}$. Thermostat-controlled lights fixed at the top of the plant canopy can aid pilots to see where air disturbances are required. It is usually advisable to fly the helicopter over the upslope side of the plants for more effective protection, because on the hill side heat transfer propagates down-slope after reaching the ground ${ }^{[51]}$. Under severe frosts conditions with higher inversions layers two helicopters must fly simultaneously with one above the other to enhance the downward heat transfer. Usually, growers and helicopter operators should meet before the frost season and strategize on flight paths. Landing site should be well lighted and clear of obstacles during the whole flight.

\section{Effectiveness of air disturbance equipment}

\subsection{Wind machines}

Wind machines for frost protection were first applied in the United States of America in the 1920s, but were not widely accepted until the $1950 \mathrm{~s}^{[57]}$. The early work demonstrated the feasibility of using wind machines as active operational tools for radiation frost protection. The machine has eventually been classified as part of air disturbance systems for frost protection. Some inconsistencies about air disturbance system's effectiveness have been found. For instance, Crawford evaluated the effectiveness of $4895 \mathrm{~N}$-thrust wind machine on influence area and the ability to increase near ground temperature and reported a linear relationship between the influenced area and the thrust value ${ }^{[58]}$. The study also revealed that $91.5 \mathrm{~m}$ away from the wind machine was the limit at which important influence can be noticed. Bates confirmed this linearity when evaluating the ability of 5827 $\mathrm{N}$-thrust wind machine to influence an area in a cherry orchard ${ }^{[59]}$. An extrapolated graph showed that the wind machine could protect an area of about $9.3 \mathrm{hm}^{2}$. A comparative study shows that near ground temperature at $79.2 \mathrm{~m}$ away from the machine was higher than that at $198.1 \mathrm{~m}$, meaning that the effectiveness of a wind machine decreased with the distance. In another study to measure vertically the temperature profile response within an apple orchard and area influence, Davis mounted temperature sensors at 1.5$18.0 \mathrm{~m}$ heights above the ground on two towers located at 52 and $104 \mathrm{~m}$ south of a wind machine ${ }^{[57]}$. Data collected on six different nights proved that wind machine operation maintained the temperature above plant critical temperature within influenced area of $2.8-3.2 \mathrm{hm}^{2}$ when the average inversion was $6.4^{\circ} \mathrm{C}$. The system also raised near ground temperature by at least $4.2^{\circ} \mathrm{C}, 1.9^{\circ} \mathrm{C}$ and $1.2^{\circ} \mathrm{C}$, over influenced areas of $0.8 \mathrm{hm}^{2}, 2.1 \mathrm{hm}^{2}$, and $3.4 \mathrm{hm}^{2}$, respectively. This once again confirms the fact that the effectiveness of a wind machine decreases with increasing distance.

Instability of wind speed influences the performance of air disturbance systems for frost protection. Therefore, how to determine the actual wind speed for effective wind machine operation is still required. To rationalize the fact that wind speed play important role in wind machine's effectiveness, Doesken and Renquist monitored the impact of a wind machine on temperature changes and frost protection of buds in an orchard when air temperature and wind speed were less than $0^{\circ} \mathrm{C}$ and $2 \mathrm{~m} / \mathrm{s}$ respectively ${ }^{[60]}$. The study revealed that under calm wind conditions, the wind machine warmed the orchard as high as $80 \%$ of the thermal inversion, but the effectiveness decreased linearly with increasing wind speed to a minimum of $20 \%$ at $2 \mathrm{~m} / \mathrm{s}$ wind speed. They further explained that irrespective of the inversion strength, wind speed above $2 \mathrm{~m} / \mathrm{s}$ was not ideal for a successful wind machine operation. In another study, Ribeiro et al. assessed whether it was important to start wind machines before reaching the critical temperature due to damping effects of thermal inversion $^{[37]}$. The study reported an instant $30 \%$ temperature rise of the inversion strength at $1.5 \mathrm{~m}$ above the ground and $30 \mathrm{~m}$ away from the wind machine. Consequently, the authors recommended that wind machines should be in operation before air temperature at $1.5 \mathrm{~m}$ dropped below critical temperature.

\subsection{Selective inverted sink}

Selective inverted sink (SIS) is a towerless wind machine and is progressively being used due to its low investment $\operatorname{cost}^{[38]}$. The SIS system was designed to modify the inversion layer by draining the coldest air, expelling it upwards to the higher and warmer strata where it is dispersed. A temperature increase is then achieved within the influence area of the device ${ }^{[45,47]}$. To prove its frost protection effect, Yazdanpanah ${ }^{[45]}$ measured plant canopy temperature and the protected area in an almond orchard. Phonological analysis showed that frost damage was lowest closed to the SIS systems; and there was a decreasing gradient of frost damage as a function of distance from the SIS. Furthermore, the results showed that bud damage in the influenced zone was averagely $20 \%$ less than the control. They concluded that the effectiveness of reducing frost damage by the SIS system was not encouraging. Therefore the deficiency does not make it a better option for frost protection. However, they suggested that a combination of the SIS with other systems like heating equipment may augment the effectiveness.

In order to assess the effectiveness of SIS and conventional wind machines, Battany compared temperature change through the operation of two SIS machines and one wind machine under similar conditions $^{[47]}$. Although protection were achieved from both equipment, the single conventional wind machine resulted in consistently larger and more significant temperature rise over a broader area compared to the two SIS machines even in combination with air drainage windbreak. Furthermore, the temperature gains observed with the SIS systems were very limited and likely to be of little benefit for vineyard frost protection even under strong inversion conditions. Battany then indicated that the results may be site-specific, and recommended further evaluation 
of the SIS systems over a broader range of conditions. In a recent study, $\mathrm{Hu}$ et al. evaluated the performance of vertical blowing fans (VBF) for frost protection in a steep slope vineyard and in hilly tea plantation $^{[46]}$. The study resulted in no temperature benefit in the steeped slope vineyard. However, the tea plantation test showed an increase in temperature at the initial VBF operation stage but that benefit was lost over time. The authors suggested that the results could be influenced by the size of the machine and the plant environment, and therefore the outcome could not validate the effectiveness of the VBF. Most studies show that SIS is not a reliable option and is recommended to run together with heaters for more effective frost protection. Some studies only focused on the plant environment as a contributing factor for its poor performance. However, the actual height of the fan above the ground, the maximum jet height, machine power, thermal inversion strength during operation and the terrain of the protected fields are less involved.

\subsection{Helicopters}

Helicopters are considered special case under wind machines, but the diversity of operation is deceptive. Wind machines are sited in particular locations but helicopters are mobile ${ }^{[58]}$. Until recently, only a few researches were made with helicopters though several commercial trials have been conducted. The interest in the helicopter application to frost protection has increased during the last few years because growers expect to achieve efficient large-scale frost protection ${ }^{[50,51]}$. Its feasibility was studied with a 47G3B-1 type helicopter hovering at different heights, speed and time interval in an orchard ${ }^{[61]}$. At the hovering height of $30.5 \mathrm{~m}$ and ground speed of $32 \mathrm{~km} / \mathrm{h}$ near ground temperature was increased by $3.5^{\circ} \mathrm{C}$ within $10 \mathrm{~min}$ after the flight started on a night with the thermal inversion strength of $10-14^{\circ} \mathrm{C}$. However, air temperature returned to the level observed before the flight started in 30-40 min. Subsequent flights at the height of 15.2 to $22.9 \mathrm{~m}$ and flight speed of $8 \mathrm{~km} / \mathrm{h}$ for two passes in 35 min provided near-ground air temperature rise of $6^{\circ} \mathrm{C}$. It took almost two hours for air temperature to drop to the original level, and the protected area was nearly $2.5 \mathrm{hm}^{2}$. Multiple passes at low speed were recommended. In another study, Miles and Hinz carried out an experiment with Sikorsky S-55-T-type helicopter at forward speeds of $40 \mathrm{~km} / \mathrm{h}, 16 \mathrm{~km} / \mathrm{h}$, and $8 \mathrm{~km} / \mathrm{h}$ in a citrus grove and recorded a clear temperature response in the region of the flight path after the third $40 \mathrm{~km} / \mathrm{h}$ pass ${ }^{[56]}$. Once again this outcome has confirmed the previous claim by Miller et al. that multiple flights have more significant effects on temperature rise and duration of protection ${ }^{[61]}$.

In recent years, the best flight parameter combination for optimizing frost protection effect has been a rapidly evolving research area for frost fighting scientists using helicopter. Based on this, $\mathrm{Hu}$ et al. verified the impacts of flight height, speed and interval on airflow disturbance of tea fields using an Unman Aerial Vehicle (UAV) and reported a linear relationship between flight parameters and rise in tea canopy temperature ${ }^{[50]}$. The study achieved only $1.6^{\circ} \mathrm{C}$ as the maximum tea canopy temperature rise after each treatment due to a very small thermal inversion of $3.8^{\circ} \mathrm{C}$ with flight time interval having the highest influence and speed having the least effect. Flight height of $4.0 \mathrm{~m}$, flight speed of $6.0 \mathrm{~m} / \mathrm{s}$ and flight time interval of $20 \mathrm{~min}$ was recommended as the optimal flight parameter combination for the possible temperature rise of $1.8^{\circ} \mathrm{C}$.

\section{Selection of air disturbance frost protection system}

An essential condition in choosing active air disturbance system for frost protection is to match the system with the prevailing frost, or dominant character of an expected frost event in a precise location ${ }^{[49]}$. Conventional wind machines, SIS also known as tower-less wind machine, ground-level mobile machines and helicopters may all provide air disturbance to fight against radiation frost. However, the above equipment matters greatly because of thermal inversion strength at the height where air mixing occurs is correlated to the system's ability to increase canopy temperature ${ }^{[37,59,62,63]}$. A thermal inversion strength less than $2.8^{\circ} \mathrm{C}$ is considered too weak for a favorable response ${ }^{[57,64]}$. Therefore, the strength, duration of thermal inversion, the number of frost night, and frost forecast should serve as a guide for growers to select the air disturbance equipment. This depends on the advantages and limitations outlined below.

Conventional wind machines do not require water resources like a sprinkler frost protection system. They do not cause any plant health problems which emanate from waterlogging of heavier soils that have restricted drainage. They can also break up micro-scale boundary layers over plant canopies which improve sensible heat transfer from the air to the plants. Wind machines have long-lasting protection periods compared to helicopters. They also have less human drudgery and operation cost compared to other equipment powered by electricity ${ }^{[51]}$. However, important limitations include: high initial investment cost (e.g., about $\$ 3000$ for small in Japan, \$28000 for portable in New Zealand, and $\$ 30000$ for large in USA). Noise produced by wind machines may excite buildings' vibration. Therefore, residents nearby wind machines may object strongly to their uses ${ }^{[64,65]}$. They are likely to be unproductive when their orientation is against the wind direction $^{[66]}$.

SIS is less expensive (e. g., SIS M 2.5 model is $\$ 7330$ with coverage area of $0.5-2.0 \mathrm{hm}^{2}$; SIS M 3.5 model is $\$ 8390$ with coverage area of $1.0-3.0 \mathrm{hm}^{2}$; SIS M 15 model is $\$ 25200$ with coverage area of $6.0-13.0 \mathrm{hm}^{2}$ ). They require much lower power and consume less fuel per hour. They are portable, easy to maintain and do not need permanent installations. The operational noise level is much lower than the conventional wind machines and helicopters. However, they have not been proven to be as effective as conventional wind machines under similar thermal inversion. In addition, their coverage is about $20 \%$ smaller than that of conventional wind machines ${ }^{[45]}$

Helicopters can significantly improve the effective protection under colder radiation frost conditions, because they apply to higher thermal inversion layer than a wind machine. A single large helicopter might protect 5 to 7 times the area of a single wind machine. Near ground temperature rise was $42 \%$ of the maximum inversion strength, which is rather difficult to be achieved by a wind machine ${ }^{[56,61]}$. However, the higher operation cost ranged between 2000 and $4000 \$ / \mathrm{hm}^{2} \cdot \mathrm{h}$, thereby used only when a black frost was forecast ${ }^{[49]}$. They also had a very short protection period because air temperature dropped back quickly prior to the next flight pass, and therefore the protection could not be sustained if the frost danger period last more than four to five hours ${ }^{[59]}$.

\section{Best management practice}

The best management practice for air disturbance equipment's 
operation is to:

i) Choose proper installation sites based on topography, wind direction, adjacent of wind machines and site conditions, such as roads, water sources or shelterbelts.

ii) Decide on the operation timing based on plant development stage and minimum air temperature during frost nights ${ }^{[67]}$.

iii) Confirm cold hardiness and critical cold temperature of the plants, and use differential thermal analysis ${ }^{[68]}$.

iv) Make good use of thermal inversion and increase air turbulence for spring and fall frost protection ${ }^{[69]}$.

v) Monitor the local real-time weather and forecast strong thermal inversion strength for automatic control.

vi) Check and maintain the machines routinely.

\section{Conclusions and prospects}

Air disturbance technology offers superior prospects for frost protection. Its merits include: 1) Improving sensible heat transfer from the air to the plants by breaking up micro-scale boundary layers over plant canopies; 2) The longest-lasting protection period over a very large area; 3) Significantly improving the effective protection under radiation frost conditions. However, its limitations include: 1) High initial cost of investment; 2) Noise produced by wind machines or helicopters, disturbing nearby residents; 3) Hard access to adequate power supply; 4) Ineffective when there is weak thermal inversion or the equipment orientation is opposite to the wind drift.

The further research and development of the technology is to optimize its structure and technical parameters, and to make it easy to use. The effectiveness of the technology has improved over the last decade. The use of air disturbance technology for frost protection is now easier with the introduction of effective automatic start-up system in collaboration with field sensors that triggers system to start when there is a strong thermal inversion with plant canopy approaching its critical temperature.

With regard to SIS, it proved that the large one appears to be more effective than the small one. Further research on the influence of fan height above the ground, the maximum jet height of the fan, machine power, thermal inversion strength during operation and the topography of the field on increasing near ground temperature could produce positive findings.

The proper hovering height, flight frequency and flight speed are still to be investigated for helicopters' efficient frost protection. The findings of most researchers suggest that a single pass is not enough to keep long protection since air temperature falls to its original level few hours after the flight. Most studies suggested multiple passes in quick successions as key factors to increase and maintain canopy temperature for a longer period. However, the actual flight parameters combination for effective protection is still unknown. Researchers are hereby encouraged to study into finding the actual flight parameters combination to enhance the effectiveness and reliability when using helicopter for frost protection.

Further studies on operations of low sound emission equipment during frost nights must be given serious attention by frost protection scientist because as it stands now, there is increasing sensitivity of the public to noise and vibrations set to homes that are close to orchards.

The next five to ten years is expected to see the incorporation of additional data into the use of air disturbance technology for frost protection. Machine designers should make use of more sophisticated design software to model and produce high efficient airfoils and blades for higher frost protection effectiveness. Researchers should focus on optimizing the geometrical parameters of the rotor, impeller and the main structure for air disturbance equipment to improve the performance of the equipment. Collecting data from meteorological stations, ground and plant canopy sensors will enable growers to correct the error in timing inversion days to minimize inefficiencies.

Overall, it is of much importance for researchers and growers to make the best design, development and better decisions on a certain air disturbance technology and equipment by understanding the working principles, control strategies, as well as the limitations of use. Hopefully air disturbance technology will enhance its efficiency and pave way for a reliable and cost-effective application.

\section{Acknowledgments}

The authors are grateful to the financial support by Jiangsu Agriculture Science and Technology Innovation Fund (CX(16)1045), Key R\&D programs of Jiangsu Province and Zhenjiang (BE2016354, NY20160120037), China and Jiangsu postdoctoral science foundations (2016M600376, 1601032C) and Priority Academic Program Development of Jiangsu Higher Education Institutions.

\section{[References]}

[1] Evans R G, Alshami A S. Pulse jet orchard heater system development: Part I. Design, construction, and optimization. Transactions of the ASAE, 2009; 52(2): 331-343.

[2] Lou W P, Qiu X F, Wu L H, Ni H P, Tang Q Y, Mao Y D. Scheme of weather-based indemnity indices for insuring against freeze damage to citrus orchards in Zhejiang, China. Agricultural Sciences in China, 2009; 8(11): 1321-1331.

[3] Lamichhane J R, Varvaro L, Parisi L, Audergon J M, Morris C E. Disease and frost damage of woody plants caused by Pseudomonas syringae: Seeing the forest for the trees. Advances in Agronomy, 2014; 126: 235-295

[4] Alshami A S, Evans R G. Pulse jet orchard heater system development: Part II. System scaling and application. Transactions of the ASAE, 2009; 52(2): 345-355.

[5] Duman J G, Wisniewski M J. The use of antifreeze proteins or frost protection in sensitive crop plants. Environmental and Experimental Botany, 2014; 106: 60-69.

[6] Gu L H, Hanson P J, Mac Post W, Kaiser D P, Yang B, Nemani R, Pallardy S G, Meyers T. The 2007 Eastern US spring freeze: Increased cold damage in a warming world. BioScience, 2008; 58(3): 253-262.

[7] Feng M C, Yang W D, Cao L L, Ding G W. Monitoring winter wheat freeze injury using multi-temporal MODIS data. Agricultural Sciences in China, 2009; 8(9): 1053-1062.

[8] Rossi F, Facini O, Loreti S, Nardino M, Georgiadis T, Zinoni F. Meteorological and micrometeorological applications to frost monitoring in northern Italy orchards. Physics and Chemistry of the Earth, Parts A/B/C, 2002; 27(23-24): 1077-1089.

[9] Ghaemi A A, Rafiee M R, Sepaskhah A R. Tree temperature monitoring for frost protection of orchards in semi-arid regions using sprinkler irrigation. Agricultural Sciences in China, 2009; 8(1): 98-107.

[10] Rodrigo J. Spring frosts in deciduous fruit trees - morphological damage and flower hardiness. Scientia Horticulturae, 2000; 85: 155-173.

[11] Szymańska R, Ślesak I, Orzechowska A, Kruk J. Physiological and biochemical responses to high light and temperature stress in plants. Environmental and Experimental Botany, 2017; 139: 165-177.

[12] Issa R J. Numerical heat transfer model for frost protection of citrus fruits by water from a spraying system. Thermal Science, 2012; 16(1): $31-42$. 
[13] Jaradat M A K, Al-Nimr M A. Smoke modified environment for crop frost protection: A fuzzy logic approach. Computers and Electronics in Agriculture, 2008; 64(2): 104-110.

[14] Król A, Amarowicz R, Weidner S. The effects of cold stress on the phenolic compounds and antioxidant capacity of grapevine (Vitis vinifera L.) leaves. Journal of Plant Physiology, 2015; 189: 97-104.

[15] Passioura J. The drought environment: physical, biological and agricultural perspectives. Journal of Experimental Botany, 2007; 58: 113-117.

[16] Cattivelli L, Rizza F, Badeck F W, Mazzucotelli E, Mastrangelo A M, Francia E, Marè C. Drought tolerance improvement in crop plants: An integrated view from breeding to genomics. Field Crop Research, 2008; 105: 1-14.

[17] Molina J G A, Hadad M A, Domínguez D P, Roig F A. Tree age and bark thickness as traits linked to frost ring probability on Araucaria araucana trees in northern Patagonia. Dendrochronologia, 2016; 37: 116-125.

[18] Atkinson C J, Brennan R M, Jones H G. Declining chilling and its impact on temperate perennial crops. Environmental and Experimental Botany, 2013; 91: 48-62.

[19] Horvath D P, Anderson J V, Chao W S, Foley M E. Knowing when to grow: signals regulating bud dormancy. Trends in Plant Science, 2003; 8(11): 534-540.

[20] Kirchhoff M, Svirshchevskaya A, Hoffmann C M, Schechert C, Jung A, Kopisch-Obuch F J. High degree of genetic variation of winter hardiness in a Panel of L. Crop Science, 2012; 52(1): 179-188.

[21] Briceño V F, Harris-Pascal D, Nicotra A B, Williams E, Ball M C. Variation in snow cover drives differences in frost resistance in seedlings of the alpine herb aciphylla glacialis. Environmental and Experimental Botany, 2014; 106: 174-181.

[22] Cittadini E D, De Ridder N, Peri P L, Van Keulen H. A method for assessing frost damage risk in sweet cherry orchards of South Patagonia. Agricultural and Forest Meteorology, 2006; 141(2): 235-243.

[23] Miranda C, Santesteban L G, Royo J B. Variability in the relationship between frost temperature and injury level for some cultivated Prunus species. HortScience, 2005; 40(2): 357-361.

[24] Skinner D Z, Garland-Campbell K A. The relationship of $\mathrm{LT}_{50}$ to prolonged freezing survival in winter wheat. Canadian Journal of Plant Science, 2008; 88(5): 885-889.

[25] Prabh T, Hoogenboom G. Evaluation of the Weather Research and Forecasting model for two frost events. Computers and Electronics in Agriculture, 2008; 6 4: 234-247.

[26] Parker L E, Abatzoglou J T. Projected changes in cold hardiness zones and suitable overwinter ranges of perennial crops over the United States. Environmental Research Letters, 2016; 11: 1-8.

[27] Winkel T, Lhomme J P, Nina Laura J P, Mamani Alcon C. Del Castillo C, Rocheteau A. Assessing the protective effect of vertically heterogeneous canopies against radiative frost: The case of quinoa on the Andean Altiplano. Agricultural and Forest Meteorology, 2009; 149: 1759-1768.

[28] Lu Y Z, Hu Y G, Li P P. Consistency of electrical and physiological properties of tea leaves on indicating critical cold temperature. Biosystems Engineering, 2017; 159: 89-96.

[29] Kalma J D, Laughlin G P, Caprio J M, Hamer P J C. The bioclimatology of frost : Its occurrence, impact and protection. In: Advances in Bioclimatology. Heidelberg: Springer-verlag, 1992; 2: pp.83-91.

[30] Perry K B. Basics of frost and freeze protection for horticultural crops. HortTechnology, 1998; 8(1): 10-15.

[31] Ball M C, Wolfe J, Canny M, Hofmann M, Nicotra A B, Hughes D. Space and time dependence of temperature and freezing in evergreen leaves. Functional Plant Biology, 2002; 29(11): 1259-1272.

[32] Hacker J, Neuner G. Ice propagation in plants visualized at the tissue level by infrared differential thermal analysis (IDTA). Tree Physiology, 2007; 27(12): 1661-1670.

[33] Wisniewski M, Bassett C, Gusta L V. An overview of cold hardiness in woody plants: Seeing the forest through the trees. HortScience, 2003; 38(5): 952-959.

[34] Wisniewski M, Glenn D M, Gusta L, Fuller M P. Using infrared thermography to study freezing in plants. HortScience, 2008; 43(6): $1648-1651$.

[35] Matzneller P, Götz K P, Chmielewski F M. Spring frost vulnerability of sweet cherries under controlled conditions. International Journal of Biometeorology, 2016; 60(1): 123-130.
[36] Woldendorp G, Hill M J, Doran R, Ball M C. Frost in a future climate: modeling interactive effects of warmer temperatures and rising atmospheric $\left[\mathrm{CO}_{2}\right]$ on the incidence and severity of frost damage in a temperate evergreen (Eucalyptus pauciflora). Global Change Biology, 2008; 14(2): 294-308

[37] Ribeiro A C, De Melo-Abreu J P, Snyder R L. Apple orchard frost protection with wind machine operation. Agricultural and Forest Meteorology, 2006; 141(2): 71-81.

[38] Vahid I, Karem C, Caroline T, Martin F, Rainvill E, Hardy G. Micrometeorological observations for the evaluation of the selective inverted sink against radiation frost and the potential of a new hybrid system. Procedia Earth and Planetary Science, 2015; 15: 920-927.

[39] Castonguay Y, Dubé M P, Cloutier J, Bertrand A, Michaud R, Laberge S. Molecular physiology and breeding at the crossroads of cold hardiness improvement. Physiologia Plantarum, 2013; 147(1): 64-74.

[40] Smyth M, Skates H. A passive solar water heating system for vineyard frost protection. Solar Energy, 2009; 83(3): 400-408.

[41] Largeron Y, Staquet C. Persistent inversion dynamics and wintertime PM10 air pollution in Alpine valleys. Atmospheric Environment, 2016; 135: 92-108.

[42] Langvalla O, Löfvenius M O. Effect of shelter-wood density on nocturnal near-ground temperature, frost injury risk and budburst date of Norway spruce. Forest Ecology and Management, 2002; 168(1-3): 149-161.

[43] Furuta M, Tomita K, Okai N. Mobile frost-prevention fan apparatus: Patent: JP200303522569, 2005-4-28.

[44] Gerber J F. Mixing the bottom of the atmosphere to modify temperatures on cold nights. In: Barfield B J, Gerber J F. Modification of the aerial environment of crops. St. Joseph, Michigan: ASAE. 1979. pp. 315-324.

[45] Yazdanpanah H, Stigter C J. Selective inverted sink efficiency for spring frost protection in almond orchards northwest of Isfahan, Iran. Theoretical and Applied Climatology, 2011; 105(1): 27-35.

[46] Hu Y G, Wu W Y, Paulo De Melo-Abreu J, Shapland T M, Zhang H, Snyder R L. Comparative experiments and effectiveness evaluation on vertical blowing fans (VBF) for frost protection. International Journal Agricultural and Biological Engineering, 2015; 8(5): 36-42.

[47] Battany M C. Vineyard frost protection with upward-blowing wind machines. Agricultural and Forest Meteorology, 2012; 157: 39-48.

[48] Guarga R F. Selective inverted drain: Patent: US5647165, 1997-1-5.

[49] Poling E B. Spring cold injury to winegrapes and protection strategies and methods. HortScience, 2008; 43(6): 1652- 662.

[50] Hu, Y G, Liu S Z, Wu W Y, Wang J Z. Shen J W. Optimal flight parameters of unmanned helicopter for tea plantation frost protection. International Journal Agricultural and Biological Engineering, 2015b; 8(5): $50-57$.

[51] Snyder R L, De Melo-Abreu J P. Frost protection: fundamentals, practice, and economics-Volume I. Rome: Food and Agriculture Organization of the United Nations, 2005.

[52] Hill D G. System for controlling operation of a crop protection wind machine array: Patent: US8608439, 2013-12-17.

[53] Tow and Blow Limited. Portable wind machines. http://www.towandblow.co.nz/. Accessed on [2018-05-15].

[54] Hu Y G, Li P P, Dai Q L, Zhang X L, Tanaka K H, Cui G L. System design and experiment on elevated wind machine for tea frost protection. Transactions of the CSAM, 2007; 38(12): 97-99. (in Chinese)

[55] Hu Y G, Li P P, Wang X H, Zhang X L. Control methods and apparatus of wind machine for frost protection: Patent: US8701341 B2, 2014-4-22.

[56] Miles J A, Hinz W W. Helicopters as frost protection devices. Transactions of the ASAE, 1976; 19(4): 672-677.

[57] Davis R L. An evaluation of frost protection provided by a wind machine in the Okanagan valley of British Columbia. Canadian Journal of Plant Science, 1977; 57(1): 71-74.

[58] Crawford $\mathrm{T}$ V. Computing the heating requirements for frost protection. Journal of Applied Meteorology, 1964; 3(6): 750-760.

[59] Bates E M. Temperature inversion and freeze protection by wind machine. Agricultural Meteorology, 1972; 9: 335-346.

[60] Doesken N J. Renquist A R. A climatological assessment of the utility of wind machines for freeze protection in mountain valleys. Journal of Applied Meteorology, 1989; 28(3): 194-205.

[61] Miller M, Perry R, Turrell F M, Hoeger H. Helicopters for frost protection. California Agriculture, 1971; 25(2): 3-4. 
[62] Reese R L, Gerber J F. An empirical description of cold protection provided by a wind machine. Journal of American Society for Horticultural Science, 1969; 94: 697-700.

[63] Renquist A R. The extent of fruit bud radiant cooling in relation to freeze protection with fans. Agricultural and Forest Meteorology, 1985; 36(1): 1-6.

[64] Goodall G E, Angus D E, Leonard A S, Brooks F A. Effectiveness of a wind machine. California Agriculture, 1957; 11(8): 7-9.

[65] Anicic O, Petković D, Cvetkovic S. Evaluation of wind turbine noise by soft computing methodologies: A comparative study. Renewable and Sustainable Energy Reviews, 2016; 56: 1122-1128.
[66] Rogers T, Omer S. The effect of turbulence on noise emissions from a micro-scale horizontal axis wind turbine. Renewable Energy, 2012; 41: $180-184$.

[67] Hu Y G, Zhu X L, Zhao M L, Snyder R L, Li P P. Operation effects of wind machines for frost protection of tea trees on different time scales. Transactions of the CSAM, 2013; 4(12): 252-257. (in Chinese)

[68] Davenport J R, Keller M, Mills L. How cold can you go? Frost and winter protection for grape. Hortscience, 2008; 43(7): 1966-1969.

[69] Mills L J, Ferguson J C, Keller M. Cold-hardiness evaluation of grapevine buds and cane tissues. American Journal of Enology Viticulture, 2006; 57(2): 194-200 